recalled to England to undertake scientific work in connexion with the supply of munitions. He rejoined Messrs. Brunner Mond and for the remainder of the War he did very valuable work in developing new processes for the manufacture of explosives. For his services to the country he was honoured with the O.B.E. In 1924, Major Freeth was awarded the doctorate in the Faculty of Mathematics and Physies in the University of Leyden. He was elected a fellow of the Royal Society in 1925.

\section{Mr. A. G. Lowndes}

Mr. A. G. Lowndes, who for the past seventeen years has been a science master at Marlborough College, is retiring at the end of the present term. Few science masters in public or other secondary schools devote themselves to original research, or have their contributions to knowledge published by scientific societies, but Mr. Lowndes, like the late Mr. Edward Meyrick, who was for many years also a master at Marlborough, but on the classical side, has had a number of original contributions published in the proceedings of scientific societies and also in the columns of NaTuRE. In 1934 he was awarded a Leverhulme research fellowship for his cinema-photomicrography. Immediately after the British Association meeting at Cambridge next month, Mr. Lowndes is going to the Leper Settlement at Oji River, Onitsha, Southern Nigeria, as a guest of the Church Missionary Society, to stay with an old pupil, Dr. David Money, who is the medical officer in.charge, and to see if useful work can be done there by a trained biologist. He proposes to return to England in the spring and to work at least eighteen months at the Marine Biological Laboratory at Plymouth, where he will apply his method of finding the density of living aquatic organisms to the study of plankton.

\section{Society for the Protection of Science and Learning}

Mr. David Cleghorn Thomson, formerly secretary to the Oxford University Appeal Committee, has been appointed general secretary, in succession to Mr. Walter Adams, of the Society for the Protection of Science and Learning (formerly known as the Academic Assistance Council) which for five years has been handling the academic side of the international refugee problem. Mr. Cleghorn Thomson is a graduate of the Universities of Edinburgh and Oxford; a senior history exhibitioner of Balliol, he was for seven years the B.B.C.'s chief official in Scotland. The Society for the Protection of Science and Learning, of which the Archbishop of York recently became president in succession to the late Lord Rutherford, acts as a central bureau of information regarding professors, lecturers and research workers displaced in their own country on account of 'race', religious or political opinions, and aids in securing the continuation of their valuable work in other countries. So far, of the 1350 displaced scholars registered with this Society, 520 have been permanently placed in 38 countries, apart from more than 300 who have temporarily found work. Within the last three months, the Society has received 340 applica- tions from scholars who have had to discontinue academic activity in Austria. The offices of the Society are at 6 Gordon Square, London, W.C.1.

\section{Atlantic Flight with 'Pick-a-Back' Start}

Mercury, the seaplane upper component of the Short-Mayo composite aircraft, arrived at the airport of Boucherville near Montreal on July 21 at 12.20 p.m. Eastern Daylight Time, having flown from Foyne, County Limerick, in a little more than twenty hours. The actual time from shore to shore, Foyne to Cape Baulewn, Newfoundland, was 13 hours 29 minutes. Considerable rain and head winds were experienced during the flight, the machine arriving at Montreal with only about eighty gallons of fuel left. After refuelling, she took off for New York, reaching there about two hours later. Captain Bennett, the pilot, and $\mathrm{Mr}$. Coster, the wireless operator, stated that they had experienced no unexpected difficulties during the journey, and had used their automatic pilot quite successfully as necessary. The machine carried a cargo of newspapers, newsreels, and photographs, principally of the royal visit to Paris. The newspapers were on sale in New York on the day following their publication. The successful finishing of this flight represents the completion of one of the experiments upon the problem of launching aircraft with excessive loading, due to the necessity for carrying considerable fuel and oil for long-distance flights. Other methods such as catapulting, topping up with fuel while in the air, etc., are being developed, and have been mentioned in NATURE as they have occurred.

\section{Depredations of Property by Rabbits}

A BrLL to protect agriculture from the ravages of rabbits was introduced in the House of Lords by Lord Sempill on July 25. It follows the lines of the report issued by the Mersey Committee on this subject, and provides powers for enabling the county councils to take action against the owner or occupier of rabbit-infested land who fails to take precautions to prevent damage to neighbouring land. It also provides for action for damages on the part of the aggrieved party. To meet the difficulties of those who are unable to find the labour and equipment necessary for keeping down rabbits, the Bill enables county councils to provide staff and equipment for this purpose. Gin traps, however, are not to be used by the staff so provided. Some doubt has been expressed as to whether the destruction of rabbits by cyanide fumigation, which may now be regarded as the standard method of rabbit-control, is strictly legal, and a clause of the Bill puts the use of this method for rodents beyond doubt. The Bill also gives effect to the Mersey Committee's recommendation that "gin traps should in no circumstances be set in the open".

Special provision is made in the Bill for instances in which Scottish legal practice and administration differ from the English. The introduction of the Bill is in the nature of a reconnaissance and has been 
undertaken in the hope that it may facilitate the passage next session of legislation on similar lines. The promoters have a two-fold objective; first, to bring some relief to farmers who are suffering from the depredations of rabbits coming from neighbouring property, and secondly, by reducing the stock of wild rabbits in the country, to reduce the amount of suffering inflicted annually by the rabbit-trapping industry. A leaflet written by a Bedfordshire farmer, with illustrations by a Bedfordshire farm labourer, has been issued in support of the Bill, and copies of this, together with a memorandum summarizing the details of the Bill, may be obtained from ULAWS (The University of London Animal Welfare Society), 42 Torrington Square, London, W.C.1.

\section{Prehistory and Quaternary Geology of the Sahara}

THE first international meeting for the Study of the Prehistory and Quaternary Geology of the Sahara was held under the auspices of the Musée de l'Homme, Paris, on June 27-30. Sir Robert Mond, who has arranged for the publication of the results, was président d'honneur, and Prof. P. Rivet, who kindly allowed the magnificent organization of his new Museum to be used, was president. Archæological papers predominated at the meeting, and of these the larger number dealt with the numerous and important rock-drawings and rock-paintings of the Desert. This being the first general meeting of men of science working in different areas of almost half a continent, it was more exploratory than definitive, the primary purpose being to familiarize workers with progress in other parts. Perhaps, not least important was the opportunity for personal contact. A second meeting will be held four years hence. However, certain more concrete results were obtained. Machinery was set up for forming a bibliography of rock paintings and drawings. It was agreed that in the pre cameline era two clear periods of rock pictures were to be found throughout the entire area, an early 'level' of hunters and a later one of cattle breeders. Further subdivisions appear at present to be local, and it also seems as if the hunters differed in different localities, whereas the cattle breeders were probably the same people throughout the Sahara. Furthermore, there was common accord that one genre of pottery is found throughout, though it varies slightly locally. The biggest uniform group stretches across the entire southern half and is the same as the Early $C$-Group culture of Nubia and a similar culture found by the Robert Mond Expedition at Armant. Its date of entry into Egypt is fixed at about 2500 B.c. The papers read at the meeting will be published later in full.

\section{Iron Age Site in Wiltshire}

THE experiment of the Prehistoric Society in undertaking excavation on an archæological site in Wiltshire, hitherto known only from air survey, with the view of providing at the same time a training ground for young archæologists (see NATURE, July 9, p. 65) has fully justified itself so far as concerns the archæological results, which, after a month's ex- cavation, have proved of considerable interest. The site selected was the lesser of two enclosures at Woodbury on the hill south of Salisbury. A test excavation had shown that it had been thickly inhabited at a period definitely belonging to the Early Iron Age. According to a preliminary report (The Times, July 20) not only did excavation confirm the existence of the pits inferred from the evidence of the air survey, but it also revealed others not so indicated. Further study of conditions affecting the two groups will no doubt prove of value in the future development of the technique of air photography. In addition to isolated pits and post-holes, there is a large group of intercommunicating shallow pits appearing on the photographs as what has come to be known as "the Great Dark Mark". Finds included a blue bead of the Early Iron Age and quantities of Early Iron Age pottery. No Romano-British remains were found. The pits were evidently for storage; and the excavators conclude that such pits, with their vertical sides, cannot be regarded, as hitherto, as pit-dwellings. The burnt material adduced as evidence of hearths, it has been shown at Woodbury by intensive study in situ, was not formed in the pits, but was thrown into them. The discovery of a similar enclosure on a hill above Harnham about a quarter of a mile away leads to the suggestion that the site now occupied by Salisbury was surrounded by a ring of such enclosures. There are others at Cockey Down and north-east of the aerodrome at Old Sarum. The complicated nature of the site will probably necessitate a second season's excavation, although the duration of the present term of digging will depend upon the funds available, towards which contributions are needed. These may be addressed to the Hon. Treasurer, Department of British and Medieval Antiquities, British Museum, Bloomsbury, London, W.C.1.

\section{Destructive Earthquake in Greece}

ON July 20, about 2.15 a.m. Athens was shaken by an earthquake which lasted about 10 seconds, and probably had its epicentre in the Island of Eubœa (Negroponte) in the AEgean Sea. The depth of focus appears to have been normal (10-15 km.), and the area in which the earthquake was destructive was about 5,000 square miles. Eight villages near Oropos were seriously damaged, seventeen people were killed, and about eighty injured. There appears to have been some fault displacement near Halcoussie. No damage appears to have been done in the capital. Greece is well known to be a centre of seismic activity in historic times, though of recent years the epicentres have been chiefly about $38.5 \mathrm{~N}$. lat., $22.5 \mathrm{E}$. long., which is north-west of Athens. Very close to the present epicentre was an earthquake which occurred on April 27, 1894, and which did damage over an area of 3,000 square miles. Permanent surface movement in this 1894 shock was for thirty-five miles along a well-known fault parallel to the Gulf of Eubcea. The ground to the north-east side of the fault was moved slightly to the north-west and depressed by varying amounts from place to place, but never greater than $5 \mathrm{ft}$. 